\title{
ГЕМАТОЛОГІЧНІ ЗМІНИ ТА ЕФЕКТИВНІСТЬ КОМБІНОВАНОЇ ТЕРАПІЇ ЗА ГЕНЕРАЛІЗОВАНОЇ ФОРМИ ДЕМОДЕКОЗУ СОБАК
}

\author{
Ю. Довгій., І. Прихода, М. Довгій
}

Поліський начіональний університет

За результатами досліджень інтенсивності інвазії демодекозу у хворих собак за генералізованої форми демодекозу встановлено,щчо на 10 - добу лікування цей показник знизився 3 17,9 \pm 0,79 до 5,9 \pm 0,20 екземплярів клішів у мазку, а на 20 - добу живих збудників виявлено не було . Результат був однаковим для тварин, які отримали дектомакс + сірково-дегтярний лінімент + тілозин 5\%, та для тих, яких лікували за схемою детомакс + екстракт личинок воскової молі 2,5\% + сірково -дегтярний лінімент з додаванням личинок воскової молі + тілозин 5\%. Дектомакс проявив 100\% ефективність щзодо збудників демодекозу, а засоби симтоматичної терапії не впливали на його акарищидну дію щзодо демодекозу. У результаті щуоденого клінічного обстеження досліджених собак 1 - ой групи було встановлено, щцо свербіж у них повністю зникає на 5 - добу лікування повне відновлення апетиту реєстрували на 10 - ту, гнійники та вузлики загоювались на 16 - ту, вирівнювання поверхні та стоншення враженої шкіри - на 21 - шу, відростання шерсті на уражених ділянках шкіри починалось на 24 - ту добу.

Завдяки додатковому застосуванню препаратів, щз містять личинок воскової молі тваринам 2 - ої дослідної групи, вдалося досягти аналогічних результатів на 3, 5,10, 15 та 18 ту добу лікування відповідно.

Морфологічне дослідження крові дослідних тварин на 30 - добу лікування показало,що застосування комплексу препаратів тваринам другої дослідної групи призвело до достовірного зменшення кількості лейкоцитів у крові з 11,40 $\pm 0,35$ до $8.90 \pm 0,31$ Г/л ( на 21,9\%, р в т.ч.-

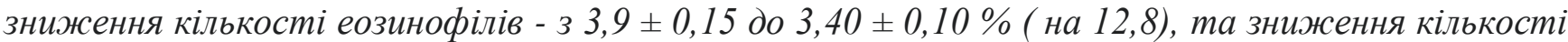
паличко ядерних нейтрофілів з 5,70 \pm 0,20 до 4,80 \pm 0,77\% (на 15,8) порівняно з показниками собак, яким застосували тільки дектомакс, сірково - дегтярний лінімент та тілозин 5\%. $(p<0,05)$.

За нормалізацію функціонування гепатоцитів вказували показники вмісту гемоглобіну, альбумінів, загального білірубіну а також активності АлАТ і АсАТ на 10 - ту, 20 - ту та 30 - ту добу лікування.

Ключові слова: собаки, кров, препарат, воскова моль, кліщі.

Постановка проблеми. Акарози - це хронічні захворювання, що викликаються акарифорними кліщами.

Ветеринарне значення мають два ряди кліщів Acariformes: ( збудник хвороб) i Parasitoformes (переносники збудників хвороб [1, с. 160; 2, с. 143].

Автори стверджують, що найбільш поширеними акарозами домашніх мясоїдних $\epsilon$ отодектоз, демодекоз, саркоптоз собак та нотоедроз котів [3, с: 92; 4, с. 85]. Хвороба характеризується дерматитами, гіперкератозами і прогресуючим схудненням.

В ускладнених випадках залучається вторинна гнійна мікрофлора: стафілококи, стрептококи, протей та умовно - патогенні грибки. Нерідко захворювання закінчується виснаженням та загибеллю. Хворіють усі види тварин, але собаки, велика рогата худоба, вівці, кози, свині перехворівають у більш важкій формі [5, с. 22; 6, с. 337].

Літературні джерела свідчать, що демодекоз - широко розповсюджене захворювання собак і котів у Німеччині. Єгипті, США, Індії, Польщі, Англії, Франції, Росії Україні. Рідко зустрічається у собак до 3 - х років. Звичайно спостерігається у тварин від 3-ох місяців до року [7, c. 30].

Аналіз актуальних досліджень. На думку вчених, Demodex canis - один з найпоширеніших паразитів у собак. Їхніми носіями є приблизно 50\% дорослих тварин. Багато дослідників вважають, що у високорезистентних тварин ( до 40 \% поголів'я) кліщ може бути присутнім в організмі упродовж усього життя, не виключаючи розвитку захворювання [8, с. 168; 9, с. 122]. Точного пояснення цьому не знайдено, однак можна припустити, що значну роль у цьому відіграють особливості імунної системи організму тварини. 
Молодняк найчастіше заражається від матері в перші години життя, при контакті з їі мордою i сосками під час облизування чи годівлі. У вагітних сук та кішок. D.canis може розмножуватися по сосках і морді. Зараження дорослих тварин зустрічається вкрай рідко, але можливість передачі збудника через предмети догляду виключати не можна [10, с.29].

Ряд авторів стверджують, що збудники демодекозу часто можуть виживати та навіть розмножуються в інших тканинах чи паренхіматозних органах.

Кліщі та їх яйця знаходили лімфатичних вузлах, стінках та просвіті кишечника, в печінці, селезінці,нирках, що свідчило про високу пристосувальну активність збудника. Хворі тварини часто облизуються, тому кліщі можуть бути виявлені, при копрологічному дослідженні [11, с. 22; 12, с. 91].

Ряд авторів рекомендують, що лікувальні заходи за акарозів собак і котів необхідно проводити в чотирьох основних напрямках : знищення збудника в органах і тканинах $[13, \mathrm{c.191}$; 14,c.80]; боротьба із супутніми інфекціями: протизапальна терапія; підвищення загальної резистентності й імунного статусу організму тварини [15, с.94; 16, с.201].

Мета статті. Розробити схеми лікування за генералізованої форми демодекозу, зміни гематологічних показників та їх ефективність.

Дослідження проводили у Навчально-науково-виробничій клініці ветеринарної медицини та кафедрі паразитології, вет.сан. експертизи та зоогігієни Поліського національного університету м. Житомир. Для наукових досліджень відібрано 3 групи собак одна (контрольна) та дві (дослідні) по 8 голів у кожній. Групи комплектували із метисів віком 1-3 років масою тіла 12-16 кг, від 1 року до 3-ох.

Для визначення інтенсивності інвазії (II) кліщів зшкрібки шкіри досліджували вітальним методом за Присєлковою, життєздатність кліщів визначали через 2, 12 та 24 години за допомогою світлового мікроскопа за малого збільшення. Проби крові відбирали зранку до годівлі з Vena cephilica antebrachii. Відбір крові, консервування, обробку та іiї зберігання здійснювали згідно 3 існуючими методиками. Гематологічні показники визначали загальноприйнятими методами [17]. Ефективність препаратів щодо збудників акарозів визначали, досліджуючи за вітальним методом Присєлкової змиви з поверхонь.

Тварини обох дослідних груп за генералізованої форми демодекозу собакам дослідних груп призначали дектомакс (США, діюча речовина - доремектин 1,0\% підшкірно, двічі з інтервалом 10 діб. М'ясоїдним обох дослідник груп перші 10 діб лікування було застосовано щоденну зовнішню обробку уражених ділянок шкіри сірково-дегтярним лініментом (сірка, березовий дьоготь та тетравіт в пропорції 2:1:4), але для тварин другої групи до нього додавали попередньо подрібнених у ступці личинок воскової молі 1:4. У подальшому до кінця лікування обробку лініментом проводили 1 раз на 2 доби.

За генерелізованої форми демодекозу собакам обох дослідних груп додатково застосовували ін'єкції антибіотика тілозин 5\% ( Бровафарма, Україна, діюча речовина тілозину тертрат 50 мл на 1,0). Його застосовували внутрішньом'язово, один раз на добу упродовж 5-ти діб у дозі 1,5/10кг маси тіла (Рис.1.)
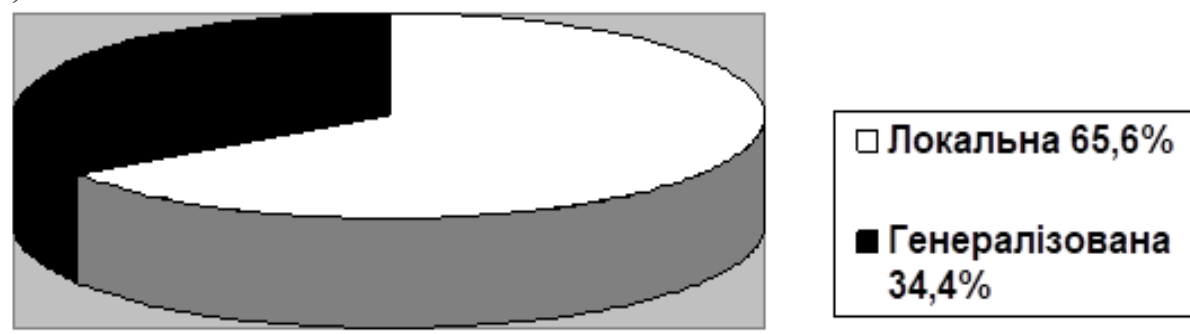

Рис. 1. Форми перебігу демодекозу собак у залежності від площі ураження.

Статистичну обробку одержаного матеріалу проводили шляхом визначення середнього арифметичного (M), його похибки (m) та рівня вірогідності (p) з використанням таблиці tкритеріїв Ст'юдента.

Виклад основного матеріалу. Враховуючи, що за генералізованої форми демодекозу на шкірі собак включно гнійні ураження, до обох схем лікування було додатково включено застосування антибіотику широкого спекту дії (тілозин 5\% виробництва ТОВ «Бровафарма », 
Україна, діюча речовина - тілозину тартрат 50 мг на 1,0 ). Його застосовували внутрішньом'язово, один раз на добу протягом 5 днів у дозі 1,5/10кг маси тіла.

За результатами дослідження інтенсивності інвазії D.canis у хворих собак за генералізованої форми демодекозу встановлено, що на 10-ту добу лікування цей показник знизився з 17,9 $\pm 0,79$ до 5,9 \pm 0,20 екземплярів кліщів у мазку, а на 20 - ту добу живих збудників виявлено не було. Важливо, що результат був однаковим для тварин, які отримували дектомакс + сірково-дегтярний лінімент + тілозин 5\% та для тих, яких лікували за схемою дектомакс + екстракт личинок воскової молі 25\% - ий + сірково-дегтярний лінімент з додаванням личинок воскової молі + тілозин 5\%. Це означає, що дектомакс проявив 100\% ефективність щодо збудників демодекозу, а засоби симптоматичної терапії не впливали на його акарицидну дію щодо D.Canis (Рис.2.)

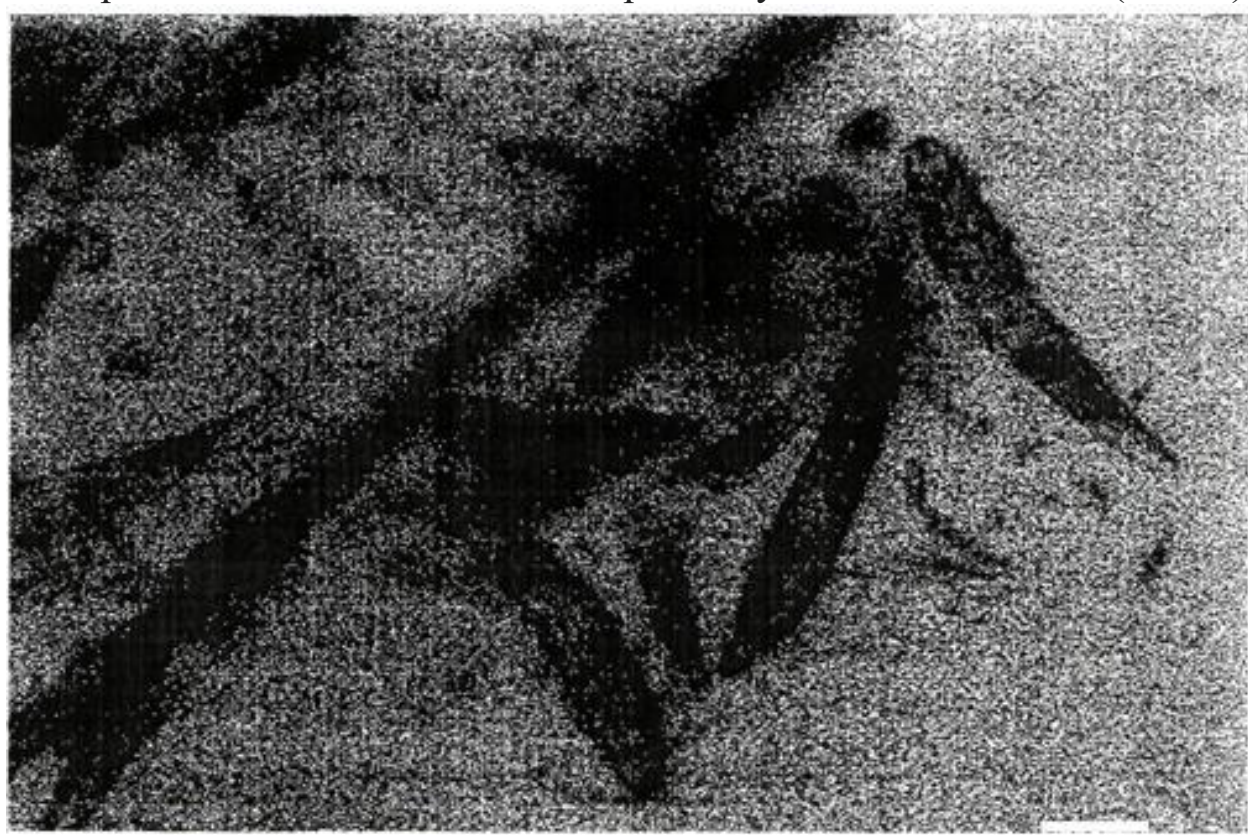

Рис. 2. Дорослі кліщі Demodex canis у зскрібку шкіри собак

У результаті щоденного клінічного обстеження дослідних собак 1-ої групи було встановлено, що свербіж у них повністю зникав на 5 -ту добу лікування, повне відновлення апетиту реєстрували на 10-ту, гнійники та вузлики загоювались на 16-ту, вирівнювання поверхні та стоншення враженої шкіри - на 21-шу, відростання шерсті на уражених ділянках шкіри починалось на 24-ту добу. Завдяки додатковому застосуванню препаратів, що містять личинок воскової молі тваринам 2-ої дослідної групи, вдалося досягти аналогічних результатів на $3,5,10$, 15 та 18 -ту добу лікування відповідно.

Для визначення відмінностей впливу різних способів лікування на загальний стан організму собак, були проведені гематологічні дослідження.

Серед морфологічних показників крові собак найбільш виразними були відмінності вмісту лейкоцитів та співвідношення їх типів у тварин різних дослідних груп. Так, на 10-ту добу від початку лікування собак, яким застосовували дектомакс, сірково-дегтярний лінімент 3 додаванням личинок воскової молі, екстракт личинок воскової молі $25 \%$-ий та тілозин 5\%, у їх

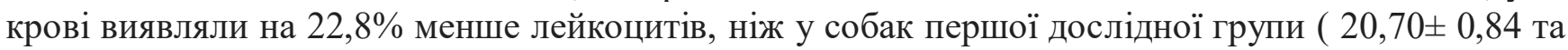

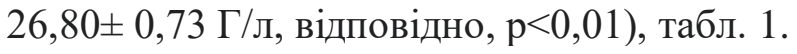

Також у собак другої дослідної групи вдалося досягти зниження кількості базофілів 3 5,50 \pm 0,19 до 3,20 \pm 0,12\% ( на 41,8\%, p<0,001), еозинофілів - $311,40 \pm 0,41$ до 7,60 $\pm 0,28 \%$ (на33,3\%, $\mathrm{p}<0,001)$, підвищення кількості сегментоядерних нейтрофілів - 3 48,10 $\pm 2,05$ до 56,00 $\pm 2,31 \%$ $(16,4 \%, p<0,05)$ порівняноз показниками тварин, яким застосовували лише дектомакс, сірководегтярний лінімент та тілозин 5\%.

Позитивний вплив препаратів, до складу яких входять личинки воскової молі, на динаміку морфологічних показників собак за генералізованого демодекозу було підтверджено результатами повторного дослідження на 20-ту добу лікування. 
Таблиця 1. Морфологічні показники крові собак, інвазованих D.canis, за генералізованої форми демодекозу, на 10-ту, 20-ту та 30-ту добу лікування, $\mathrm{M} \pm \mathrm{m}$

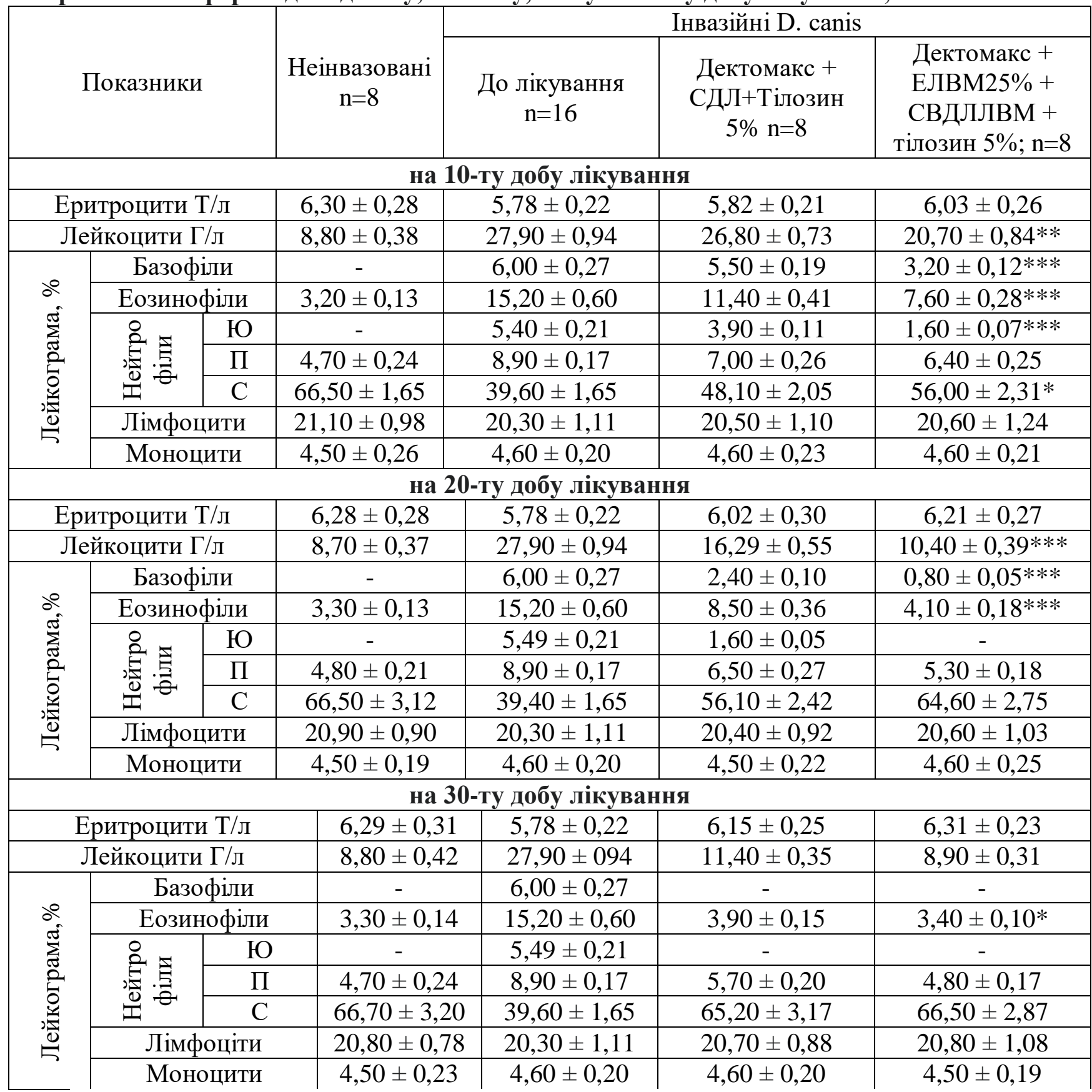

Примітка. **p $<0,01, * * * p<0,001$ - порівняно з групою лікування дектомаксом + сірково- дегтярним лініментом + тілозин 5\%.

Так, застосування комплексу препаратів тваринами другої дослідної групи призвело до достовірного зменшення кількості лейкоцитів у крові з 16,20 \pm 0,55 до 10,40 \pm 0,39 Г/л ( на 35,8\%,

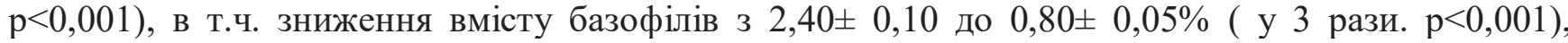
еозинофілів - з 8,50 $\pm 0,36$ до 4,10 $\pm 0,18 \%$ (у 2,1 рази, $\mathrm{p}<0,001)$, зниження юних нейтрофілів ( в

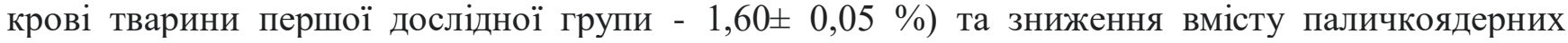
нейтрофілів - 6,50 \pm 0,27 до 5,30 $\pm 0,16 \%$ (18,5\%, p $<0,01)$ порівняно з показниками собак, яким застосовували тільки дектомакс, сірково-дегтярний лінімент та тілозин 5\%.

Не зважаючи на відсутність збудників демодекозу в зшкрібках зі шкіри інвазованих собак, за результатами клінічного та гематологічного дослідження тварин було вирішено продовжити курс лікування ще на 10 діб. Морфологічне дослідження крові дослідних тварин на 30-ту добу лікування показало, що застосування комплексу препаратів тваринами другої дослідної групи

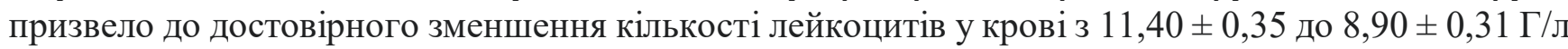


( на 21,9\%, p <0,01), в т.ч зниження кількості еозинофілів - з 3,90 $\pm 0,15$ до 3,40 $\pm 0,10 \%$ ( на 12,8

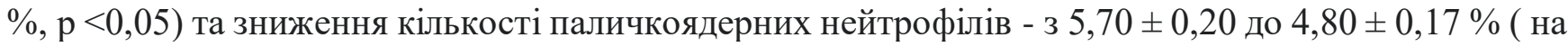
$15,8 \%, \mathrm{p}<0,05)$ порівняно 3 показниками собак, яким застосували тільки дектомакс, сірководегтярний лінімент та тілозин 5\% ( табл. 2). Зниження вмісту лейкоцитів у крові собак при додаванні до курс терапії екстракту личинок воскової молі, є ознакою того, що діючі речовини цих засобів прискорюють відновлення систем та органів тварин під час одужання, знижують інтенсивність запальних та алергічних процесів. Адже у крові собак цієї дослідної групи найвиразнішими змінами є зниження кількості еозинофілів та базофілів, які з'являються в крові у відповідь на гострий запальний процес, сенсибілізацію чи інтоксикацію організму. Таким чином, зменшення їх вмісту є ознакою ефективного одужання дослідних тварин.

Результатами дослідження біохімічних показників крові собак, хворих на демодекоз у генералізованій формі,підтвердили стимулюючий вплив препаратів, що містять личинок воскової молі,на відновлення організму під час одужання (табл. 2).

Таблиця 2. Біохімічні показники крові, інвазованих D.canis, за генералізованої форми демодекозу, на 10-ту добу лікування, $\mathrm{M} \pm$ m

\begin{tabular}{|c|c|c|c|c|}
\hline \multirow[b]{2}{*}{ Показники } & \multirow[b]{2}{*}{$\begin{array}{c}\text { Неінвазовані } \\
. \mathrm{n}=8\end{array}$} & \multicolumn{3}{|c|}{ Інвазійні D. canis } \\
\hline & & $\begin{array}{c}\text { До лікування } \\
\mathrm{n}=16\end{array}$ & $\begin{array}{c}\text { Дектомакс } \\
+ \text { СДЛ+Тілозин } \\
5 \% \text { n=8 }\end{array}$ & $\begin{array}{c}\text { Дектомакс + } \\
\text { ЕЛВМ } 25 \%+ \\
\text { СДЛЛВМ + } \\
\text { тілозин 5\% n=8 }\end{array}$ \\
\hline Гемоглобін г/л & $14970 \pm 7,03$ & $114,90 \pm 4,82$ & $115,10 \pm 4,36$ & $122,80 \pm 4,10$ \\
\hline Заг.білок,г/л & $66,21 \pm 2,85$ & $52,73 \pm 1,81$ & $54,12 \pm 2,24$ & $61,71 \pm 2,13^{*}$ \\
\hline Альбуміни, г/л & $34,14 \pm 1,52$ & $23,65 \pm 0,75$ & $25,48 \pm 1,05$ & $31,29 \pm 1,34$ \\
\hline Альбуміни \% & 51,56 & 44,85 & 47,08 & 50,70 \\
\hline Заг. альцій, ммоль/л & $2,78 \pm 0,15$ & $2,63 \pm 0,11$ & $2,64 \pm 0,13$ & $2,66 \pm 0,15$ \\
\hline Заг.білірубін, мкмоль/л & $3,10 \pm 0,13$ & $8,09 \pm 0,34$ & $8,02 \pm 0,28$ & $6,57 \pm 0,23 * *$ \\
\hline Холестерин, ммоль/л & $4,59 \pm 0,20$ & $5,26 \pm 0,21$ & $5,16 \pm 0,21$ & $4,74 \pm 0,15$ \\
\hline Креатинін, мкмоль/ & $88,18 \pm 4,32$ & $93,25 \pm 4,50$ & $92,18 \pm 3,56$ & $91,24 \pm 3,84$ \\
\hline Сечовина ммоль/л & $4,81 \pm 0,22$ & $9,71 \pm 0,39$ & $9,27 \pm 0,26$ & $7,14 \pm 0,19 * *$ \\
\hline АлАТ, Од/л & $22,93 \pm 0,90$ & $103,29 \pm 4,30$ & $89,18 \pm 4,00$ & $51,43 \pm 2,25 * * *$ \\
\hline АсАТ, Од/л & $14,65 \pm 0,61$ & $72,15 \pm 3,53$ & $68,84 \pm 2,88$ & $43,69 \pm 1,62 * * *$ \\
\hline ЛФ, ОД/л & $73,12 \pm 3,07$ & $118,60 \pm 4,39$ & $115,76 \pm 4,16$ & $92,68 \pm 3,90 * *$ \\
\hline
\end{tabular}

Примітка. *p<0,05, **p<0,01, p <0,01 - порівняно з групою лікування дектомаксом + сірководегтярним лініментом + тілозин $5 \%$.

Так, на 10-ту добу лікування тварин, яким застосовували дектомакс, сірково-дегтярний лінімент $з$ додаванням личинок воскової молі та екстракт личинок воскової молі 25\% - ий,вдалося досягти достовірного підвищення концентрації загального білка з 54,12 \pm 2,24 до 61,71 \pm 2,13 г/л ( на 14,0 \%, p <0,05), альбуміну - $325,48 \pm 1,05$ до $31,29 \pm 1,34$ г/л (на 22,8 \%, p <0,05), зниження вмісту загального білірубіну з 8,02 $\pm 0,28$ до $6,57 \pm 0,23$ мкмоль/л ( на $18,1, \%, p<0,01$ ) та сечовини з 9,27 \pm 0,26 до 7,14 $\pm 0,19$ ммоль/л ( на 23,0\%, p<0,01), а також активності ферментів АлАТ 3 $89,18 \pm 4,00$ до 51,43 2,25 Од/л(на 42,3 \%, p<0,01), АсАТ- $з$ 68,84 $\pm 2,88$ до 43,60 $\pm 1,62$ Од/л (на $19,9 \%, \mathrm{p}<0,01)$ порівняно з аналогічними показниками тварин,яких лікували лише дектомаксом, сірково- дегтярним лініментом та тілозином $5 \%$.

На 20-ту добу досліду в крові собак,яким застосовували дектомакс, екстракт личинок воскової молі 25 \%-ий, сірково-дегтярний лінімент з додаванням личинок воскової молі та тілозин 5 \%, порівняно з показниками тварин, яких лікували поєднанням дектомаксу, сірково-дегтярного лініменту та тілозину 5\% спостерігали ряд достовірних змін (табл. 3). Так, у тварин 2-ої дослідної групи реєстрували підвищення вмісту гемоглобіну - 3 119,40 \pm 4,22 до 148,30 \pm 5,16 г/л( на 24,2 $\%, \mathrm{p}<0,01)$, альбумінів - $328,32 \pm 0,93$ до 33,83 $\pm 1,36$ г/л ( на 19,5\%,p<0,05),зниження концентрації загального білірубіну з $6,54 \pm 0,22$ до 4,08 $\pm 0,16$ мкмоль/л (на $12,8 \%, p<0,05$ ), а також зниження активності ферментів АлАТ з 54,17 $\pm 2,23$ до 24,82 \pm 0,88 Од/л ( у 2,2 рази,р<0,001), 
АсАТ $з$ 49,39 \pm 2,12 до 15,89 \pm 0,64 Од/л ( у 3,1 рази,р<0,001) та ЛФ $з$ 96,55 \pm 4,29 до 71,85 $\pm 3,28$ Од/л ( на 25,6 \%,p<0,01).

Таблиця 3. Біохімічні показники крові,інвазованих D.canis, за генералізованої форми демодекозу, на 20-ту добу лікування, $\mathrm{M} \pm$ m

\begin{tabular}{|c|c|c|c|c|}
\hline \multirow[b]{2}{*}{ Показники } & \multirow[b]{2}{*}{$\begin{array}{c}\text { Неінвазовані } \\
\mathrm{n}=8\end{array}$} & \multicolumn{3}{|c|}{ Інвазійні D. canis } \\
\hline & & $\begin{array}{c}\text { До лікування } \\
\text { n=16 }\end{array}$ & $\begin{array}{c}\text { Дектомакс } \\
+ \text { СДЛ+Тілозин } \\
5 \% \\
\mathrm{n}=8\end{array}$ & $\begin{array}{c}\text { Дектомакс + } \\
\text { ЕЛВМ25\% + } \\
\text { СВЛЛВМ + } \\
\text { тілозин 5\% n=8 }\end{array}$ \\
\hline Гемоглобін г/л & $151,30 \pm 6,94$ & $114,90 \pm 4,82$ & $115,10 \pm 4,36$ & $148,30 \pm 5,16 * *$ \\
\hline Заг.білок,г/л & $66,32 \pm 2,96$ & $52,73 \pm 1,81$ & $54,12 \pm 2,24$ & $63,75 \pm 3,10$ \\
\hline Альбуміни, г/л & $34,17 \pm 1,40$ & $23,65 \pm 0,75$ & $25,48 \pm 1,05$ & $33,83 \pm 1,36^{*}$ \\
\hline Альбуміни \% & 51,52 & 44,85 & 49,48 & 53,07 \\
\hline Заг. альцій, ммоль/л & $2,77 \pm 0,12$ & $2,63 \pm 0,11$ & $2,72 \pm 0,16$ & $2,77 \pm 0,12$ \\
\hline Заг. білірубін, мкмоль/л & $3,11 \pm 0,16$ & $8,09 \pm 0,34$ & $6,54 \pm 0,22$ & $4,08 \pm 0,16^{* *}$ \\
\hline Холестерин, ммоль/л & $4,57 \pm 0,22$ & $5,26 \pm 0,21$ & $4,84 \pm 0,18$ & $4,62 \pm 0,19$ \\
\hline Креатинін, мкмоль/ & $88,33 \pm 4,25$ & $93,25 \pm 4,50$ & $30,1 \pm 4,56$ & $89,29 \pm 0,19$ \\
\hline Сечовина ммоль/л & $4,82 \pm 0,23$ & $9,71 \pm 0,39$ & $6,18 \pm 0,23$ & $5,39 \pm 0,20 *$ \\
\hline АлАТ, Од/л & $22,52 \pm 1,04$ & $103,29 \pm 4,30$ & $54,17 \pm 2,23$ & $24,82 \pm 0,88 * * *$ \\
\hline АсАТ, Од/л & $14,68 \pm 0,69$ & $72,15 \pm 3,53$ & $49,39 \pm 2,12$ & $15,89 \pm 0,64 * * *$ \\
\hline ЛФ,ОД/л & $72,86 \pm 3,51$ & $118,60 \pm 4,39$ & $96,55 \pm 4,9$ & $71,85 \pm 3,28 * *$ \\
\hline
\end{tabular}

Примітка. *p $<0,05, * * p<0,01, \mathrm{p}<0,001$ - порівняно 3 групою лікування дектомаксом + сірководегтярним лініментом + тілозин $5 \%$.

На 30-ту добу досліду в крові собак, яким застосовували дектомакс, екстракт личинок воскової молі $25 \%$-ий, сірково-дегтярний лінімент з додаванням личинок воскової молі та тілозин 5\%,порівняно з показниками тварин,яких лікували поєднанням дектомаксу,сірководегтярного лініменту та тілозину 5\%,спостерігали зниження концентрації загального білірубіну 3 4,56 \pm 0,17 до 3,21 $\pm 0,10$ мкмоль/л ( на 29,6\%, p<0,001),a також зниження активності ферментів АлАТ $з$ 43,19 $\pm 1,67$ до 22,54 \pm 1,07 Од/л (на 47,8\%, p<0,001), АсАТ-з 28,40 $\pm 1,13$ до 14,72 $\pm 0,48$

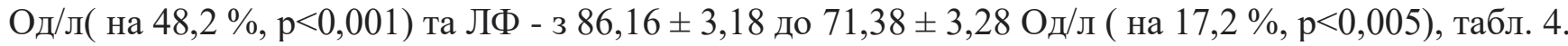

Таблиця 6. Біохімічні показники крові, інвазованих D.canis, за генералізованої форми демодекозу, на 30-ту добу лікування, $\mathrm{M} \pm$ m

\begin{tabular}{|c|c|c|c|c|}
\hline \multirow[b]{2}{*}{ Показники } & \multirow[b]{2}{*}{$\begin{array}{c}\text { Неінвазовані } \\
\mathrm{n}=8\end{array}$} & \multicolumn{3}{|c|}{ Інвазійні D. canis } \\
\hline & & $\begin{array}{c}\text { До лікування } \\
\mathrm{n}=16\end{array}$ & $\begin{array}{c}\text { Дектомакс } \\
+ \text { СДЛ+Тілозин } \\
5 \% \\
\mathrm{n}=8\end{array}$ & $\begin{array}{c}\text { Дектомакс + } \\
\text { ЕЛВМ } 25 \%+ \\
\text { СДЛЛВМ + } \\
\text { тілозин 5\%; n=8 }\end{array}$ \\
\hline Гемоглобін г/л & $152,70 \pm 7,05$ & $114,90 \pm 4,82$ & $137,50 \pm 4,56$ & $155,40 \pm 5,37$ \\
\hline Заг.білок, г/л & $66,56 \pm 3,26$ & $52,73 \pm 1,81$ & $63,73 \pm 2,71$ & $66,33 \pm 4,26$ \\
\hline Альбуміни, г/л & $34,24 \pm 1,54$ & $23,65 \pm 0,75$ & $312,80 \pm 1,02$ & $34,27 \pm 1,32$ \\
\hline Альбуміни \% & 51,44 & 44,85 & 49,90 & 51,67 \\
\hline Заг. Кальцій, ммоль/л & $2,78 \pm 0,14$ & $2,63 \pm 0,11$ & $2,78 \pm 0,12$ & $2,79 \pm 0,14$ \\
\hline $\begin{array}{l}\text { Заг. білірубін, } \\
\text { мкмоль/л }\end{array}$ & $3,13 \pm 0,15$ & $8,09 \pm 0,34$ & $4,56 \pm 0,17$ & $3,21 \pm 0,10 * *$ \\
\hline Холестерин, ммоль/л & $4,53 \pm 0,19$ & $5,26 \pm 0,21$ & $4,64 \pm 0,24$ & $4,55 \pm 0,16$ \\
\hline Креатинін, мкмоль/ & $89,06 \pm 4,33$ & $93,25 \pm 4,50$ & $89,50 \pm 4,55$ & $88,81 \pm 4,37$ \\
\hline Сечовина ммоль/л & $4,80 \pm 0,25$ & $9,71 \pm 0,39$ & $5,29 \pm 0,16$ & $4,78 \pm 0,12 *$ \\
\hline АлАТ, Од/л & $22,18 \pm 0,78$ & $103,29 \pm 4,30$ & $43,19 \pm 1,67$ & $22,54 \pm 1,07 * * *$ \\
\hline АсАТ, Од/л & $14,63 \pm 0,61$ & $72,15 \pm 3,53$ & $28,40 \pm 1,13$ & $14,72 \pm 0,48 * * *$ \\
\hline ЛФ, ОД/л & $71,90 \pm 3,21$ & $118,60 \pm 4,39$ & $86,16 \pm 3,18$ & $71,38 \pm 3,28 * *$ \\
\hline
\end{tabular}

Примітка. ${ }^{*} \mathrm{p}<0,05, * * \mathrm{p}<0,01, \mathrm{p}<0,001$ - порівняно з групою лікування дектомаксом + сірководегтярним лініментом + тілозин 5\% 
Отримані нами дані вказують на те, що діючі речовони препаратів, які вмістять личинок воскової молі, сприяють прискоренню репараційних процесів у організмі собак під час одужання після загоювання на генералізовану форму демодекозу.

На відновлення структури печінки та нормалізацію функціонування гепатоцитів вказували показники вмісту гемоглобіну, альбумінів,загального білірубіну, а також активності АлАТ і АсАТ на 10-ту, 20-ту та 30-ту добу лікування.

На припинення руйнування тварин шкіри та прискорення їх відновлення вказував показник вмісту сечовини в сироватці крові дослідних тварин.

\section{Висновки}

1. Дектомакс проявив $100 \%$ ефективність щодо збудників демодекозу,а засоби симптоматичної терапії не впливали на його акарицидну дію щодо D.canis.

2. Діючі речовини препаратів, які містять личинок воскової молі, сприяли прискоренню репараційних процесів у організм собак під час одужання після захворювання на генералізовану форму демодекозу.

3. Показники вмісту гемоглобіну, альбумінів, загального білірубіну, а також активності АлАТ і АсАТ на 10-ту, 20-ту та 30-ту добу лікування,вказували на відновлення структури печінки та нормалізації функціювання гепатоцитів.

4. Зниження умісту сечовини до фізіологічної межі в сироватці крові дослідних тварин, вказували на припинення руйнування тканин шкіри та прискорення їх відновлення.

Перспективи подальших досліджень будуть цілеспрямовані на розробку лікування на організм собак за саркоптозу.

\section{Список використаних джерел}

1. Wol R. ( 2006 ). Taxonomic priority in Psoroptes mange mites: p.ovis or p.egui. Exp. Appl. Acarol.-V.39-№2.-p.159-162.

2. Bengnet Г.(2015). Comparative efficocy of two oral treatments for dogs containing either afoxalaner or fluralaner against Ripicephalus sanguineous sepsu lato and Dermacentor reticulates.

Parasitology.-№ 209- p.112-145.

3. Свстафєва В.О. (2015) Поширення акарозів собак в умовах міста Кременчуга . Вісн.Полтав. держ. аграр.акад.-№ 1/2.-с.91-94.

4. Brimer 1. (2004) Rapid guantitatiue assay for acaridae effects on Sarcoptes scabiei voor. snis and Otodectes cynotis.Exp.Appl.

Acarol-V .33.-№2.-p.81-91.

5. Nutting W.B. (1976). Hair follicle mites ( Demodex xp.) of medical and veterinary concern. Cornell Vet - V.66.-№1.-p.-21-25.

6. Hasegawa T.A. (1995).A cose report of the management of democosin the golden hamster. Vet.- Med.Sci.-V.57.-№2-p.337-338.

7. Фирсов Н.Ф.(2000).Эпизотология и терапия демодекоза собак по урбанизированих териториях юга Росии.Весн.ветеринарии.-№ 21/4/.-с.27-38.

8. Ravera I.(2013). Small Demodex populations colonize most parts of the skin of healthy dogs. Vet.Dermology.№24.-p.168-170.

9. Gaafar S.M.(1959). Apporently incidence of Demodex sp. in skins of apparently normal dogs.№133.-p.122-123.

10. Головко А.Н.(1997). Заболеваемость демодекозом собак разных пород. Зб.мат. II міжнар.наук.-практ.конф.'Проблеми ветеринарного обслуговування дрібних домашніх тварин “.К.-№3.-c.27-35.

11. Ларионов С.В.(1991) . Видовые морфологические различия клещей демодексов. Токсикология и защита сельскохозяйственных животных от эктопаразитов .М.,-с.20-30.

12. Слесарева Д.А.(2007). Энтеросорбция в комплексной терапии больных демодекозом.Tp.V Науч.- практ. конф. «Актуальные вопросы патологии кожи и урогенитальных инфекцый». - Одесса - c.90-91.

13. Letendre L.(2014). The intravenous and oral pharmacokinetics afoxolaner, a novel isoxazoline, used as a monthly clewable antiparasitic for dogs. Vet.Parasitology.-№201.-p.190-`197. 
14. Mueller R.S.(2004).Treatment protocols for demodicosis: an evidence baset review.Vet.Dermatology.-V.15.-p.75-89.

15. Слесарева Д.А.(2007) Комплексные подходы к лечению демодекоза в практике дерматокосметолога . Мат. наук.- практ. конф. « Сучасний менеджмент в дерматовенерології : діягностичні, лікувальні та організаційно- прарові аспекти» .- Київ.-с.93-94.

16. Опанасюк А.С.(2000). Применения дектомакса при демодекозе собак. Пробл. стабилизации и развития сел. хоз-ва Казахстана, Сибири и Монголии.- Новосибирск.-с.190.

17. Корпищенко А.И.(1997). Медицинская лабораторная диагностика .Санкт- Петербург: интермедика - 297 с.

\section{ГЕМАТОЛОГИЧЕСКИЕ ИЗМЕНЕНИЯ И ЕФФЕКТИВНОСТЬ КОМБИНИРОВАННОЙ ТЕРАПИИ ПРИ ГЕНЕРАЛИЗИРОВАННОЙ ФОРМЕ ДЕМОДЕКОЗА СОБАК} Довгий Ю., Прихода И., Довгий М.

По результатам исследований интенсивности инвазии демодекоза у больных собак по генерализованной формы демодекоза установлено, что на 10 - сутки лечения этот показатель снизился с 17,9 \pm 0,79 до 5,9 \pm 0,20 экземпляров клещей в мазке, а на 20 - сутки живых возбудителей обнаружено не было. Результат был одинаковым для животных, получивших дектомакс + серная -дегтярний линимент + тилозин 5\%, и для тех, которые лечили по схеме детомакс + экстракт личинок восковой моли 2,5\% + серной -дегтярний линимент с добавлением личинок восковой моли + тилозин $5 \%$. Дектомакс проявил 100\% эффективность в отнотении возбудителей демодекоза, а средства симтоматическая терапии не влияли на его акарицидным действием в отношении демодекоза. В результате каждый день клинического обследования исследованных собак первой группь было установлено, что зуд в них полностью исчезает на 5 сутки лечения полное восстановление аппетита регистрировали на 10 - ту, гнойники и узелки заживали на 16 - ту, выравнивания поверхности и истончение пораженной кожи - на 21 - ю, отрастания шерсти на пораженных участках кожи начиналось на 24 - е сутки.

Благодаря дополнительному применению препаратов, содержащих личинок восковой моли животным второй опытной группы, удалось достичь аналогичных результатов на 3, 5, 10, 15 и 18 - е сутки лечения соответственно.

Морфологическое исследование крови подопытных животных на 30 - день лечения показало, что применение комплекса препаратов животным второй опытной группы привело к достоверному уменьшению количества лейкочитов в крови с 11,40 \pm 0,35 до $8.90 \pm 0,31$ г / л (на

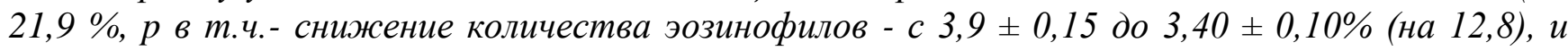

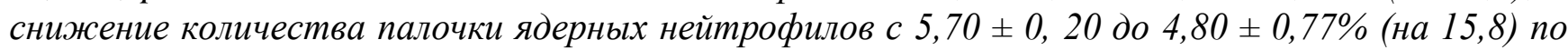
сравнению с показателями собак, которым применили только дектомакс, серная - Дегтярный линимент и тилозин 5\%. (p <0,05).

За нормализаџию функиионирования гепатоцитов указывали показатели содержания гемоглобина, альбумина, общего билирубина а также активности АлАТ и АсАТ на 10 - ю, 20 - $е$ и 30 - е сутки лечения.

Ключевые слова: собаки, кровь, препарат, восковая моль, клещии.

\section{HEMATOLOGICAL CHANGES AND THE EFFECTIVENESS OF THERAPY ACCORDING TO GENERALIZED FORM OF DOGS' DEMODICOSIS}

Dovhiy U., Prichoda M., Dovhiy M.

The study of demodecosis invasion intensity in dogs under a generalized form of demodecosis has established that on the 10th day of treatment this index decreased from $17.9 \pm 0.79$ to $5.9 \pm 0,20$ tick specimen in a smear, and on the 20th day no active disease agent was registered.The result was similar for animals which received Dectomax + Sulphurous-tar leniment + Tylosin, and for those which were treated according to the schedule: Dectomax $+2.5 \%$ Waxworm extraction + Sulphurous-tar leniment + Waxworm $+5 \%$ Tylosin. Dectomax showed $100 \%$ effectiveness as to demodecosis agents, but disease management therapy did not have any impact on its acaricide effect as to demodecosis. After a daily clinical examination of dogs of the first experimental group it has been found that the itches dissappeared on the 5th day of treatment, the appetite appeared on the 10th day, fistula and nodules skinned over on the 16th day, the affected skin got softer and thinner on th 21st day, canine hair on the affected skin ares 
started growing on the 24th day. The animals of the second experimental group additionally received preparations containing Waxworm, thus analogical results were achieved on the $3 \mathrm{rd}$, 5th, 10th, 15th and 18th day of treatment respectively.

The morphological examination of animals blood on the 30th day of treatment showed that after treating animals of the second experimental group with a complex of preaparations, the amount of leucocytes in blood decreased from $11.40 \pm 0.35$ to $8.90 \pm 0.31 \mathrm{~g} / \mathrm{l}$ ( by 21.9\%), eosinophiles amount decreased from $3.9 \pm 0.15$ to $3.40 \pm 0.10 \%$ (by 12,8), the amount of banded neutrophiles decreased from $5.70 \pm 0.20$ to $4.80 \pm 0.77 \%$ (by 15.8) as compared to the indices of the dogs which received only Dectomax + Sulphurous-tar leniment $+5 \%$ Tylosin $(p<0.05)$.

The indices of hemoglobulin, albumen, total bilirubin as well as of AlAT and AcAt activity on the 10th, 20th and 30th day of treatment confirm the normalization of hepocytes functioning.

Key words:dogs, blood, drug, wax moth, mites. 